\section{Commentary: In pursuit of a pediatric heart valve that can grow with the child}

\section{Sitaram M. Emani, MD}

Congenital heart surgeons unfortunately still find the need to adapt adult prosthetic valves to fit pediatric applications. The manuscript by Griffiths and colleagues ${ }^{1}$ highlights the harsh reality that the search for a durable pediatric prosthesis will be fraught with numerous failures. The hypothesis underlying this case series was reasonable-valves designed for transcatheter implantation may function as expandable valves for pediatric applications. After all, experience with a stented bovine jugular vein graft in the mitral or tricuspid position had previously shown promise in this regard. ${ }^{2}$ At first glance, one would expect a stented trileaflet bovine pericardial valve to function similarly well. ${ }^{3}$ However, this series demonstrated suboptimal performance due to leaflet immobility at relatively short-term follow-up. Mechanical valves remain a viable option for patients with annulus diameter of greater than $15 \mathrm{~mm}$, but the promise of an expandable heart valve for growing children remains elusive.

When designing an expandable pediatric heart valve, several considerations arise. First and foremost is leaflet material. Unlike pyrolytic carbon, biological tissues are prone to degradation from cyclic stress and calcification from numerous mechanisms. The "inertia" of the leaflet, attributable to its mass and stiffness, plays important role in the mobility of the leaflet during the cardiac cycle. Infants with low cardiac output compared with adults experience low flow across the valve. Opening forces are less in the atrioventricular valve positions compared with the outflow positions, due to the low driving pressure gradient between

\footnotetext{
From the Department of Cardiovascular Surgery, Boston Children's Hospital, Boston, Mass.

Disclosures: Dr Emani is a consultant for Cheisi Pharmaceuticals.

The Journal policy requires editors and reviewers to disclose conflicts of interest and to decline handling or reviewing manuscripts for which they may have a conflict of interest. The editors and reviewers of this article have no conflicts of interest.

Received for publication Oct 31, 2020; revisions received Oct 31, 2020; accepted for publication Nov 6, 2020; available ahead of print Nov 24, 2020.

Address for reprints: Sitaram M. Emani, MD, 300 Longwood Ave, Boston, MA 02115 (E-mail: Sitaram.emani@cardio.chboston.org).

JTCVS Techniques 2021;5:87-8

2666-2507

Copyright (C) 2020 The Authors. Published by Elsevier Inc. on behalf of The American Association for Thoracic Surgery. This is an open access article under the CC BY-NCND license (http://creativecommons.org/licenses/by-nc-nd/4.0/).

https://doi.org/10.1016/j.xjtc.2020.11.022
}

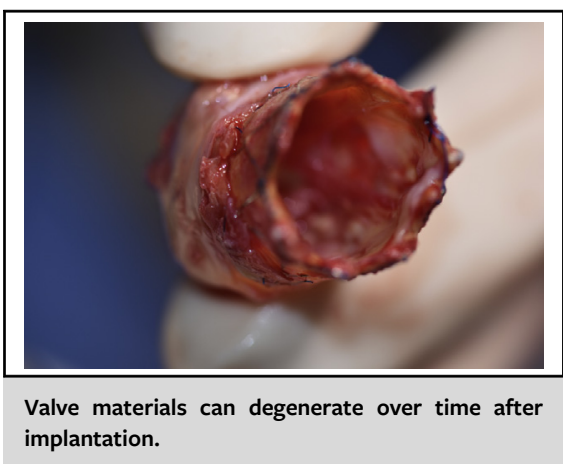

\section{CENTRAL MESSAGE \\ Expandable valve technology re- mains an elusive target for congenital heart surgeons. We are learning important lessons from this series.}

the atrium and ventricle during diastole. Poor mobility of a leaflet early after implantation may set the stage for thrombosis, fibrin formation, and pannus ingrowth, which lead to early valve deterioration (Figure 1). Another important consideration is the leaflet configuration for an expandable valve. Venous valves were designed by nature to maintain competence over a range of diameters, and valves that have been modeled based upon the venous valve have shown promise. ${ }^{5,6}$ Essential features of the venous valve include the tall commissural height and hammock-shaped leaflets. ${ }^{7}$ Most bovine pericardial valves are designed to function well at a prescribed diameter but may buckle if underexpanded or separate if overexpanded. Given the small size of the pediatric annulus, a minimal valve housing

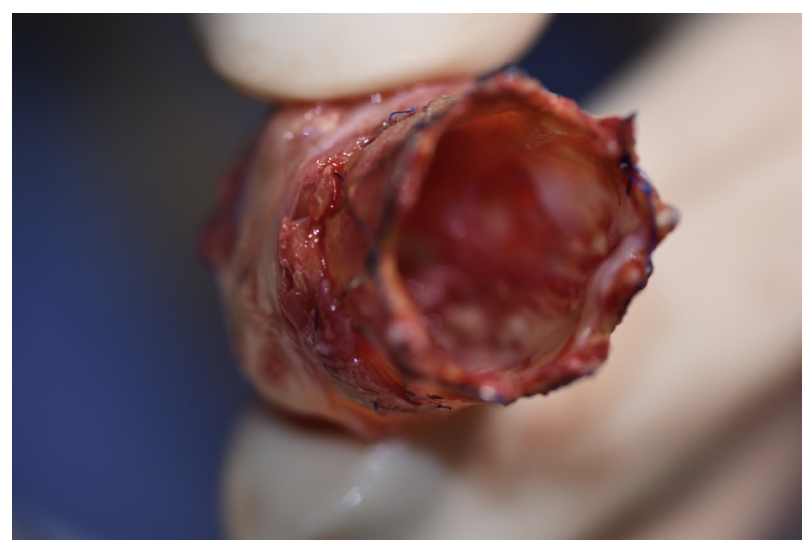

FIGURE 1. Valve materials can degenerate over time after implantation. 
is key to maximizing effective orifice area. Wire mesh stents are ideal in this regard, since they support a valve without occupying much space.

The bovine pericardial valve implanted in this series has certain favorable features-excellent effective orifice area, an expandable stent housing that is relatively fractureresistant, and low rate of endocarditis in adult populations. However, the disadvantages lie in the material properties and valve design. Bovine pericardium is thick and stiff, even after painstaking processing. This leads to poor mobility in the atrioventricular valve position. The design does not accommodate for incomplete expansion, and underexpansion may contribute further to leaflet immobility and deterioration. The lessons learned from this experience will help us in our choice of off-label valve prostheses but more importantly guide future development of pediatric heart valves.

\section{References}

1. Griffiths E, Gray RG, Martin MH, Husain SA, Eckhauser AW. Limited durability of expandable pericardial tissue valves in the mitral position in children. $J$ Thorac Cardiovasc Surg Tech. 2021;5:84-6.

2. Emani SM, Piekarski BL, Zurakowski D, Baird CA, Marshall AC, Lock JE, et al. Concept of an expandable cardiac valve for surgical implantation in infants and children. J Thorac Cardiovasc Surg. 2016;152:1514-23.

3. Chai PJ, George I, Nazif TM, Kalfa DM, Kodali SK, Torres AJ, et al. Use of stented bovine pericardial valve for surgical mitral valve replacement in infants. J Thorac Cardiovasc Surg. 2016;151:e51-2.

4. Eltayeb OM, Readdy WJ, Monge MC, Forbess JM, Sarwark AE, Patel A, et al. Mitral valve replacement in infants using a $15-\mathrm{mm}$ mechanical valve. Ann Thorac Surg. 2019;108:552-7.

5. Pluchinotta FR, Piekarski BL, Milani V, Kretschmar O, Burch PT, Hakami L, et al. Surgical atrioventricular valve replacement with melody valve in infants and children. Circ Cardiovasc Interv. 2018;11:e007145.

6. Hofferberth SC, Saeed MY, Tomholt L, Fernandes MC, Payne CJ, Price K, et al. A geometrically adaptable heart valve replacement. Sci Transl Med. 2020;12: eaay4006.

7. Hammer PE, Roberts EG, Emani SM, Del Nido PJ. Surgical reconstruction of semilunar valves in the growing child: should we mimic the venous valve? A simulation study. J Thorac Cardiovasc Surg. 2017;153:389-96. 